\title{
Analisa dan Implementasi Sistem Keamanan Router Mikrotik dari Serangan Winbox Exploitation, Brute-Force, DoS
}

\author{
Haeruddin \\ Ilmu Komputer, Teknologi Informasi, Universitas Internasional Batam, Batam, Indonesia \\ Email: haeruddin@uib.ac.id \\ Email Penulis Korespondensi: haeruddin@uib.ac.id
}

\begin{abstract}
Abstrak-Kemajuan perkembangan teknologi semakin memudahkan untuk mencari dan berbagi informasi apapun dengan menggunakan jaringan komputer. Jaringan komputer telah banyak diterapkan di rumah dan perkantoran. Kemudahan pertukaran data di jaringan membuat ketersediaan jaringan komputer dan keamanan informasi rentan terhadap ancaman serangan. Pada jaringan komputer, perangkat yang paling rentan adalah router. Router merupakan perangkat terluar yang menghubungkan Local Area Network (LAN) dengan internet sehingga dapat dengan mudah diserang oleh pihak yang tidak bertanggung jawab. Produk router Mikrotik merupakan produk yang banyak digunakan sebagai router gateway yang menghubungkan LAN dan Internet. Banyak sekali alat yang bisa digunakan untuk melakukan serangan pada router Mikrotik seperti Hping3 (DoS), Hydra (Brute-Force), Srictp Exploitation (Winbox Exploitation). Untuk mengetahui celah keamanan pada router Mikrotik, penelitian ini menggunakan metode penetration testing dengan teknik serangan seperti Winbox Exploitation, Brute-Force, dan DoS. Setelah mengetahui celah keamanan, langkah selanjutnya adalah memberikan dan mengimplementasikan rekomendasi agar serangan serupa tidak terjadi lagi di kemudian hari.
\end{abstract}

Kata Kunci: Brute-Force; DoS; Kemanan Jaringan; Penetration Testing; Router Mikrotik; Winbox Exploitation

Abstract-The advancement of technology development makes it easier to find and share any information using computer networks. Computer networks have been widely applied in homes and offices. The ease of exchanging data on the network makes the availability of computer networks and information security are vulnerable to attacks by threats. On a computer network, the device which has the vulnerability is a router. A router is the outermost device that connects the Local Area Network (LAN) to the internet so that it can be easily attacked by irresponsible parties. The Mikrotik router is a product that is widely used as a gateway router that connects LANs and the Internet. There are so many tools that can be used to carry out attacks on Mikrotik routers such as Hping3 (DoS), Hydra (Brute-Force), and Exploitation Script (Winbox Exploitation). To find out the security loop in Mikrotik routers, this study uses penetration testing methods and attack techniques such as Winbox Exploit, Brute-force, and DoS. After knowing the security gap, the next step is to provide and implementation recommendations so that similar attacks do not occur any more in the future.

Keywords: Brute-Force; DoS; Network Security; Penetration Testing; Mikrotik Router; Winbox Exploitation

\section{PENDAHULUAN}

Perangkat infrastruktur jaringan seperti router digunakan dalam interkoneksi jaringan. Perangkat yang banyak digunakan pada negara berkembang adalah router berbiaya rendah, dimana perangkat ini digunakan untuk memperluas jangkauan internet ditempat-tempat terpencil. Router berbiaya rendah adalah router yang murah dapat digunakan sebagai router rumah atau sebagai router inti pada infrastruktur jaringan dengan fitur perutean yang lebih canggih [1].

Pada jaringan komputer perangkat yang memiliki kerentanan adalah router. Router merupakan perangkat paling luar yang menghubungkan Local Area Network (LAN) dengan internet sehingga dapat dengan mudah diserang oleh pihak yang tidak bertanggung jawab [2]. Salah satu router dengan biaya rendah adalah router Mikrotik. Dari hasil pengujian dengan menggunakan honeypot didapatkan karakteristik serangan berupa Mikrotik Common Vulnerabilities and Exposures (CVE), DNS redirection, Brute-Force Attacks, Point-to-Point Tunneling Protocol, Denial-of-Service [1].

CVE merupakan kerentanan pada suatu software atau firmware perangkat keras, salah satunya pada perangkat Mikrotik. Dimana pada tahun 2018 telah ditemukan kerentanan terkait perangkat Mikrotik yaitu CVE2018-14847 yang memungkinkan akses ke router Mikrotik. Serangan ini memberikan akses ke file dan akses di rektori, serta memperoleh kredensial akun Administrator [2],[3],[4]. Serangan berikutnya adalah DNS redirection merupakan serangan yang menargetkan cache DNS pada router. Jenis serangan ini mengalihkan lalu lintas situs web yang biasa dan mengarahkan ke situs web phising [1]. Serangan ini dapat dilakukan dengan menyalahgunakan kerentanan dalam implementasi perangkat lunak router. Beberapa contoh lain dari serangan ini dapat dilakukan dengan mengirimkan paket dalam format yang salah, menyuntikkan kode berbahaya atau dengan mengeksploitasi buffer overflows [5]. Brute Force merupakan cara umum untuk mencoba meretas ke dalam sistem. Pada serangan ini peretas mencoba menggunakan kombinasi kata sandi dan nama pengguna yang umum untuk memasuki sistem. Jenis serangan yang umum dengan menggunakan kamus, yang dilakukan dengan mencoba username dan password default atau kombinasi dari kata-kata umum. Jenis serangan ini umum terjadi dan biasanya tidak terbatas pada router berbiaya rendah. Serangan lain adalah Point-to-Point Tunneling Protocol (PPTP), serangan ini diawali dari kerentanan Mikrotik yaitu CVE-2018-14847 dimana penyerang mendapatkan hak akses masuk ke router dan membuat koneksi PPTP [1]. Selain itu terdapat juga serangan Denial-of-Service [1], serangan ini sering terjadi sehingga menjadi ancaman di jaringan internet [6], intensitas dan frekuensi serangan ini naik dan 
mengkhawatirkan [7]. Serangan DoS dengan perubahan ukuran data yang besar sehingga menyebapkan router mengalami kenaikan daya dan beban kerja CPU sehingga menurungkan performa jaringa atau mengalami down [8], [9]. Pada umumnya serangan DoS yang sering di lakukan adalah pingflood atau dnsflood [10].

Serangan tersebut memberikan dampak yang bermacam-macam pada individu atau organisasi, seperti kehilangan integritas, kerahasiaan, dan ketersediaan [11]. Untuk menghidari hal tersebut, dapat melakukan pengaturan keamanan pada router Mikrotik. Untuk pengaturan keamanan ada banyak cara yang dapat di lakukan seperti menerapkan Intrusion Detection System (IDS) dengan aplikasi pihak ketiga seperti snort dan melakukan implelentasi firewall [12], namun untuk memastikan pengaturan yang benar maka harus di lakukan pengujian. Salah satu metode yang paling banyak digunakan adalah metode penetration testing [8], [9]. Penetration testing adalah metode yang banyak digunakan untuk melakukan pengujian sistem keamanan, termasuk kemanan jaringan. Metode ini bertujuan untuk mengetahui dan memastikan adanya celah keamanan suatu jaringan. Ini bertujuan agar untuk mempermudah administrator atau pemilik jaringan dalam melakukan pencegahan secara dini sebelum adanya serangan pada perangkat router Mikrotik yang dapat menimbulakan kerusakan maupun kerugian pada pengguna [15].

\section{METODOLOGI PENELITIAN}

Penelitian ini merupakan penelitian terapan dengan metode Penetration Testing. Penelitian terapan adalah penerapan langsung pada objek yang akan diteliti guna memecahkan masalah yang dihadapi, sehingga akan memberikan hasil berupa solusi yang didapatkan dari proses implementasi penelitian[13]. Penetration testing adalah metode yang digunakan untuk mencari informasi tentang target, menyerang kelemehan target, dan memberikan solusi untuk melakukan perbaikan agar celah keamanan tersebut dapat diatasi dan dihilangkan sebelum menimbulkan kerusakan maupun kerugian pada pengguna [15]. Pada penetration testing merupakan metode aktif non-standar untuk menilai pertahanan jaringan dengan mengikuti prosedur multi-fase berurutan dan interaktif yang dimulai dengan mengumpulkan informasi dan diakhiri oleh melaporkan hasil yang diperoleh [14]. Ada tiga jenis pengujian penetration teasting yaitu black hat, grey hat, dan white hat [16]. Pengujian black hat penetration testing memindai host jarak jauh tanpa memiliki pengetahuan sebelumnya tentang target yang akan diserang, kemudian melakukan analisa dan melaporkan hasilnya, pengujian grey hat penetration testing dimana penyerang telah memiliki sebagian informasi terhadap objek yang akan diserang, sedangkan white hat penetration testing serangkaian pengujian yang di lakukan dengan memiliki informasi yang signifikan terhadap objek yang akan diserang. Pengujian Penetration testing white hat yang di gunakan pada penelitian ini. Berikut fase penetration testing:

a. Pengumpulan informasi dan Perencanaan

Tahapan ini merupakan tahapan mengumpulkan informasi target yang akan diserang. Informasi bisa didapatkan dengan metode wawancara, pengamatan secara langsung, atau dari literatur review yang sudah ada. Pada tahapan ini juga menentukan perencanaan penelitian. Meliputi pemilihan topik, ruang lingkup, tujuan pengujian, dan pemilihan alat yang akan digunakan dalam pengujian.

b. Mencari celah keamanan

Tahapan ini merupakan tahapan untuk melakukan analisa dan memahami cara kerja target dalam melakukan penyerangan. Tahapan ini dilakukan dengan menggunakan alat seperti Aplikasi Nmap untuk melakukan scanning pada target sehingga melihat celah yang ada dan membantu untuk menentukan alat yang akan digunakan pada tahapan berikutnya.

c. Melakukan serangan

Tahapan ini merupakan tahapan yang paling penting dalam penelitian ini, dimana dilakukan serangan pada jaringan untuk mengetahui celah keamanan yang ada. Pada serangan ini akan menggunakan beberapa teknik yaitu Winbox Exploitation, Brute-Force, dan DoS.

d. Rekomendasi dan Implementasi

Tahapan ini memberikan hasil dan mengimplementasikan rekomendasi yang didapatkan selama penelitian untuk menghindari serangan yang akan datang.

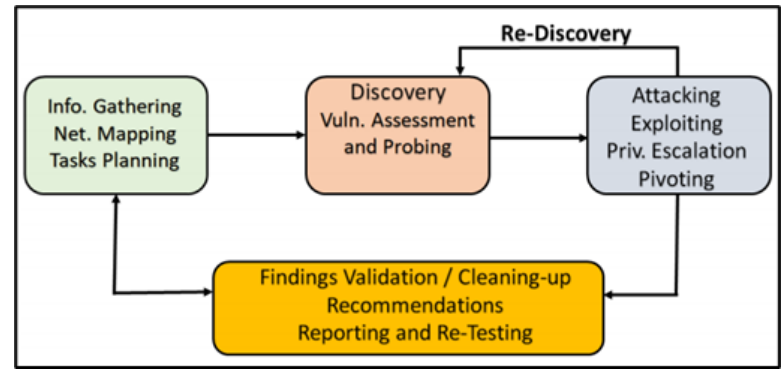

Gambar 1. Metode Penetration testing 
ISSN 2614-5278 (media cetak), ISSN 2548-8368 (media online)

Available Online at https://ejurnal.stmik-budidarma.ac.id/index.php/mib DOI 10.30865/mib.v5i3.2979

\section{HASIL DAN PEMBAHASAN}

Pada bagian ini berisi hasil dan pembahasan mengggunakan metode penetration testing dengan jenis white hat. Peneliti sangat memahami kondisi jaringan yang akan diteliti. Berikut hasil yang didapatkan dari tahapan-tahapan yang ada pada metode penetration testing.

\subsection{Metode Penetration Testing}

\subsubsection{Pengumpulan Informasi dan Perencanaan}

Pada tahapan ini melakukan pengumpulan data terkait jaringan yang akan dilakukan pengujian, seperti topologi jaringan dan pengalamatan IP address, dan konfigurasi yang ada pada sistem jaringan. Pada pengujian ini menggunakan topologi jaringan seperti pada gambar 2 di bawah ini. Router yang di gunakan adalah Router Mikrotik RB951G-2HnD, yang memiliki 5 interface gigabit ethernet, dan satu interface wlan.

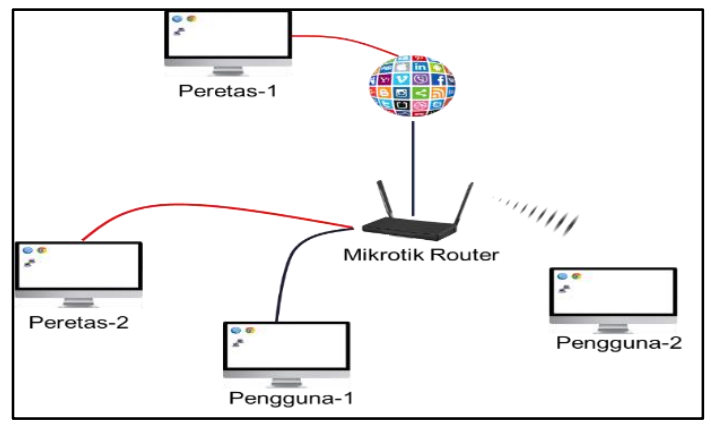

Gambar 2. Toplogi Jaringan

Pengalamatan IP address yang digunakan pada pengujian ini seperti pada tabel 1 dibawah ini.

Tabel 1. Pengalamatan IP Address

\begin{tabular}{llllll}
\hline $\begin{array}{c}\text { Nama } \\
\text { Perangkat }\end{array}$ & Interface & \multicolumn{1}{c}{ IP Address } & Gateway & Network & Ket \\
\hline Mikrotik & Ether1 & 103.206 .253 .106 & 103.206 .253 .105 & $103.206 .253 .104 / 29$ & Internet \\
\hline Mikrotik & $\begin{array}{l}\text { Bridge } \\
\text { (Ether2-5, } \\
\text { dan Wlan1) }\end{array}$ & 192.168 .88 .1 & - & $192.168 .88 .0 / 24$ & LAN \\
\hline Pengguna-1 & Ethernet & 192.168 .88 .2 & 192.168 .88 .1 & $192.168 .1 .0 / 24$ & $\begin{array}{l}\text { Pengguna } \\
\text { dengan media } \\
\text { kabel }\end{array}$ \\
\hline Pengguna-2 & Ethernet & 192.168 .88 .3 & 192.168 .88 .1 & $192.168 .2 .0 / 24$ & $\begin{array}{l}\text { Pengguna } \\
\text { dengan media } \\
\text { nirkabel }\end{array}$ \\
\hline Peretas-1 & Ethernet & Internet & & & $\begin{array}{l}\text { Peretas dari } \\
\text { Internet }\end{array}$ \\
\hline Peretas-2 & Ethernet & 192.168 .88 .4 & 192.168 .1 .1 & $192.168 .1 .0 / 24$ & $\begin{array}{l}\text { Peretas dari } \\
\text { jaringan LAN } \\
\text { dengan media } \\
\text { kabel }\end{array}$ \\
\hline
\end{tabular}

Berikut ini adalah konfigurasi dasar yang ada pada router Mikrotik.

\begin{tabular}{|c|}
\hline 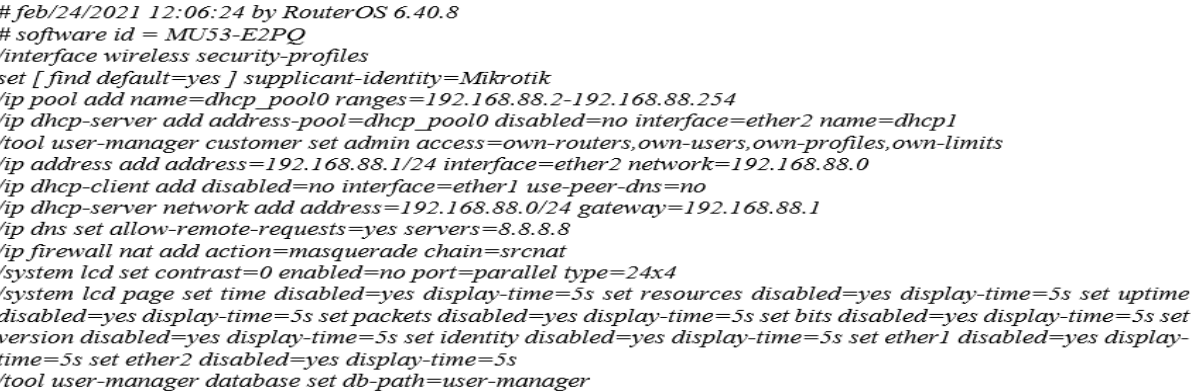 \\
\hline
\end{tabular}

Gambar 3. Konfigurasi dasar 
ISSN 2614-5278 (media cetak), ISSN 2548-8368 (media online)

Available Online at https://ejurnal.stmik-budidarma.ac.id/index.php/mib DOI 10.30865/mib.v5i3.2979

\subsubsection{Mencari celah keamanan}

Agar dapat mengetahui celah keamanan pada router Mikrotik, salah satu alat yang digunakan adalah aplikasi Nmap [17]. Aplikasi Nmap merupakan aplikasi yang digunakan scanning pada router Mikrotik agar dapat melihat celah yang ada [18]. Scan jaringan dilakukan dari sisi internet dan jaringan LAN, untuk jaringan internet IP address target adalah 103.206.253.106 yang merupakan IP publik, dan IP target di jaringan LAN adalah 192.168.88.1. Dapat dilihat seperti pada gambar 4 berikut ini.

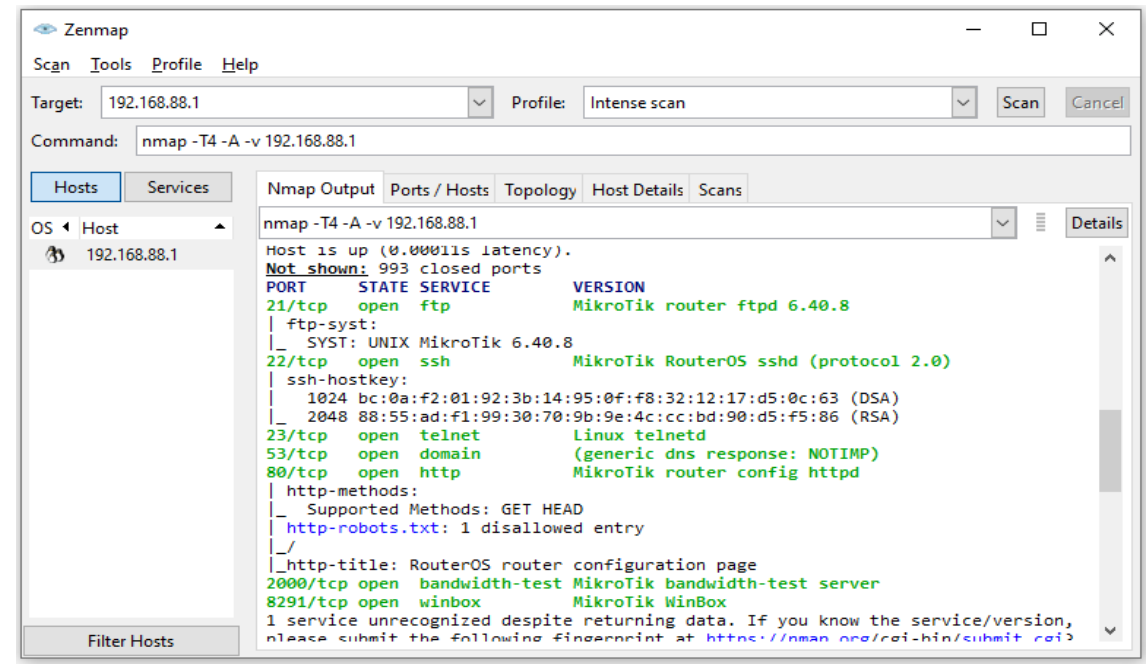

Gambar 3. Hasil scanning pada router Mikrotik dari jaringan LAN

Dari hasil scan pada router Mikrotik didapatkan tujuh port yang statusnya terbuka yaitu 21/tcp (FTP), 22/tcp (SSH), 23/tcp (Telnet), 53/tcp (DNS), 80/tcp (HTTP), 2000/tcp (Bandwith Test), dan 8291/tcp (Winbox). Dari hasil tersebut port 22, 23, 80, dan 8291 merupakan port untuk mengakses router Mikrotik, port 21 yaitu ftp untuk melakukan transfer file pada Mikrotik, dan port 53 yaitu DNS untuk mengelola penamaan untuk IP address pada

internet.

\subsubsection{Melakukan Serangan}

Setelah mendapatkan informasi penting dari hasil scanning maka tahapan berikutnya adalah melakukan pengujian serangan pada router Mikrotik, pada pengujian ini dilakukan beberapa jenis serangan sebagai berikut:

a. Winbox Exploitation merupakan serangan yang dilakukan pada router Mikrotik yang memanfaatkan celah keamanan router Mikrotik yaitu CVE-2018-14847, serangan ini dapat dilakukan pada router Mikrotik dengan versi 6.40 kebawa. Hasil yang di dapatkan setelah menjalankan file exploitation dari komputer peratas seperti pada gambar 4 di bawah ini. Pada gambar 4 dapat dilihat peretas berhasil mendapatkan username dan password router Mikrotik, dimana username $=$ admin dan password $=$ Passw0rd.

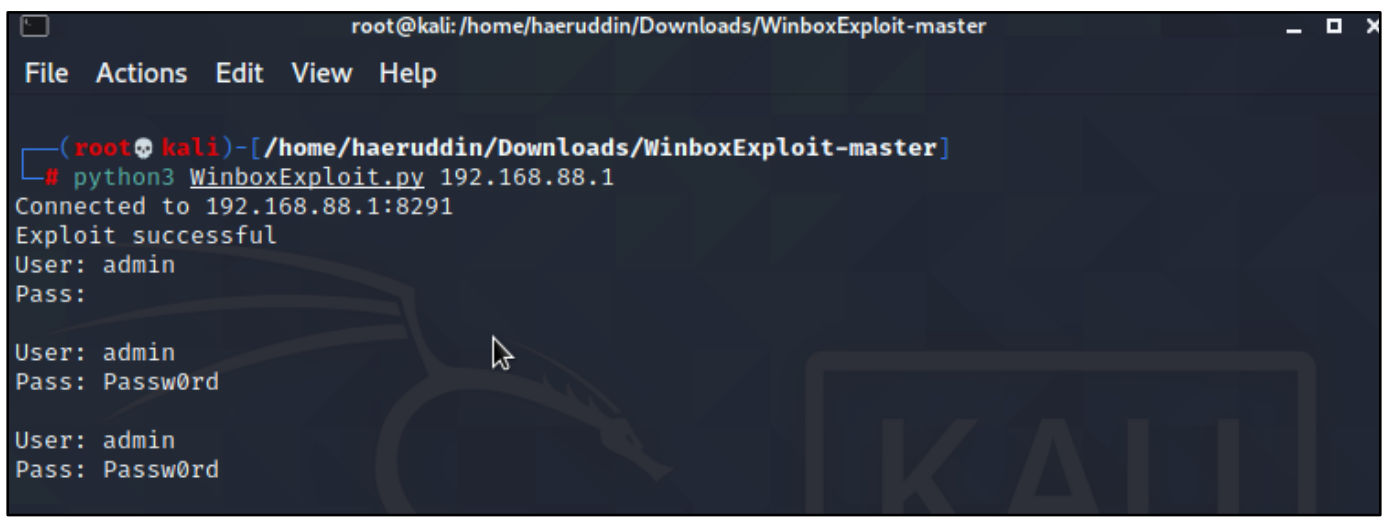

Gambar 4. Serangan Exploit pada router Mikrotik

b. Brute-Force merupakan serangan yang dilakukan pada perangkat jaringan atau server dengan mencoba menebak password yang digunakan oleh Administrator jaringan, password tersebut disimpan dalam bentuk daftar list paswword atau biasa disebut kamus. Pada pengujian ini alat yang digubakan adalah aplikasi Hydra pada Kali Linux. Protokol yang akan diserang adalah SSH. Adapun hasil yang di dapatkan seperti pada gambar 5 berikut ini. Dari pengujian yang dilakukan peretas berhasil mendapatkan username=admin dan password=Password. 
ISSN 2614-5278 (media cetak), ISSN 2548-8368 (media online)

Available Online at https://ejurnal.stmik-budidarma.ac.id/index.php/mib DOI 10.30865/mib.v5i3.2979

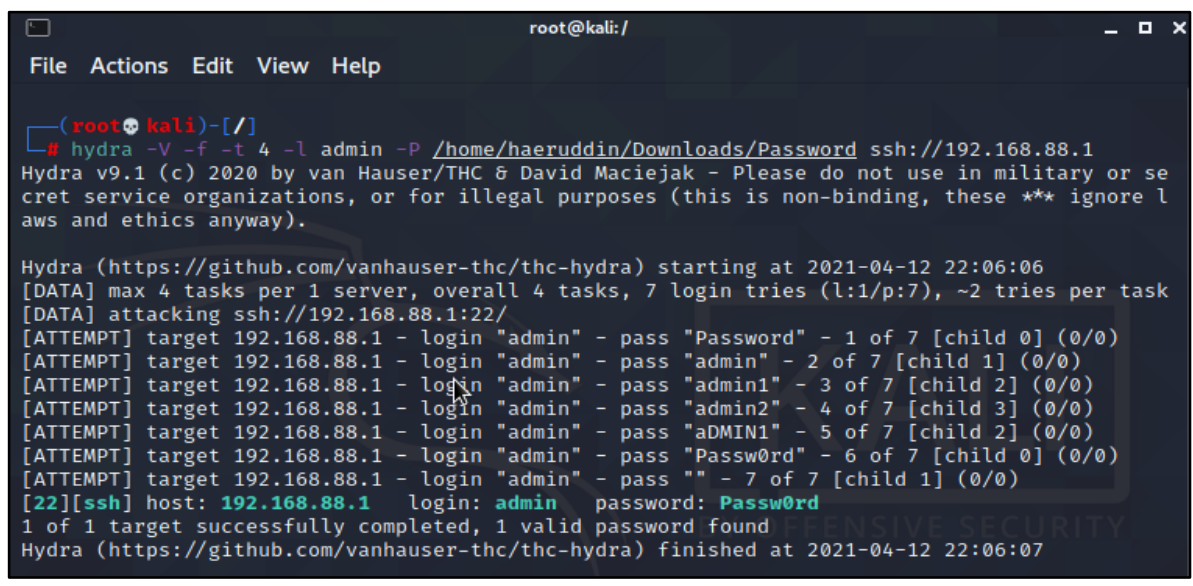

Gambar 5. Hasil Brute-force pada router Mikrotik

c. DoS merupakan serangan yang membuat jaringan sibuk bahkan terjadi down, sehingga tidak dapat melayani permintaan pengguna [8]. Akibat dari serangan ini akan menggangu operasional pada suatu organisasi ataupun rumahan. Teknik serangan ini mengguanakan DNS Flooding menggunakan aplikasi Hping3 pada Kali Linux. Serangan ini memanfaatkan protokol DNS dengan port 53, serta protokol transport UDP. Pada gambar 6 adalah perintah yang dijalankan pada aplikasi Hping3 dan pada gambar 7 adalah hasil serangan dari Hping3.

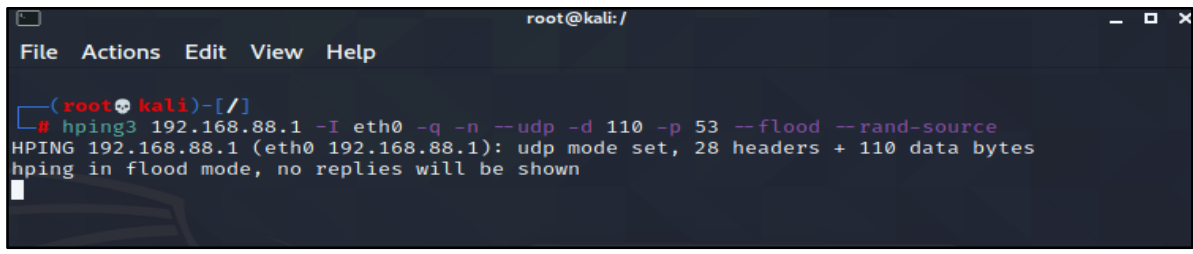

Gambar 6. Serangan DoS ke router Mikrotik menggunakan Hping3

Pada gambar 7 dapat dilihat dengan menjalankan perintah pada gambar 6 maka penggunaan CPU meningkat hingga 100\%, dan pada bagian firewall connection kita bisa melihat terjadi terdapat banyak koneksi ke protokol DNS di router Mikrotik.

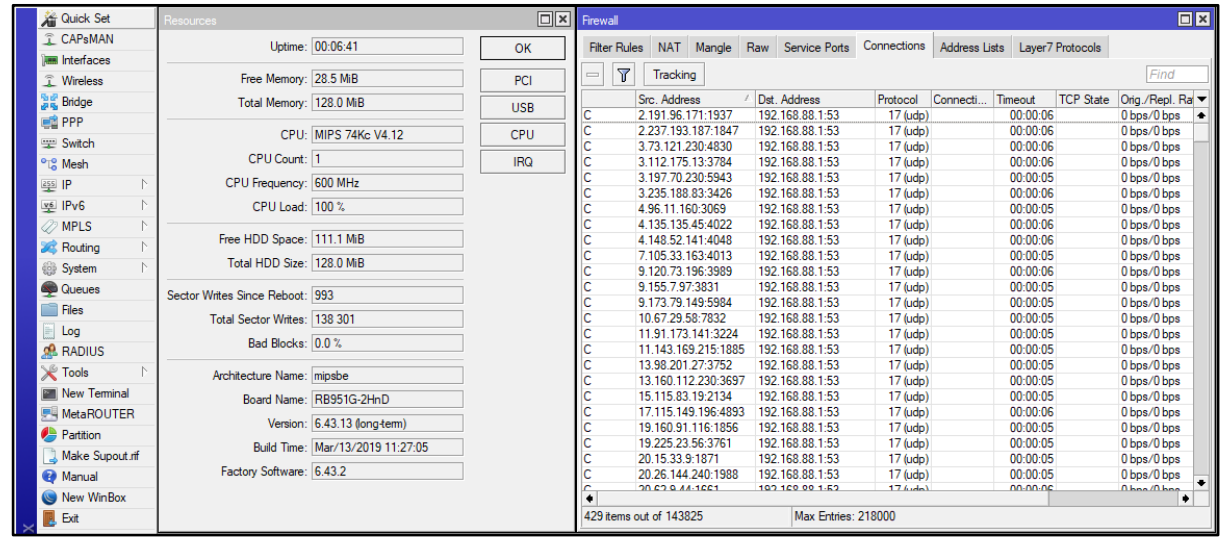

Gambar 7. Hasil serangan DoS pada router Mikrotik

Berdasarkan pengujian yang telah dilakukan (Winbox Exploitation, Brute-Force, dan DoS) hasil yang didapatkan seperti pada tabel 1 berikut ini.

Tabel 1. Hasil Serangan pada router Mikrotik

\begin{tabular}{llll}
\hline No & Jenis Serangan & Status Serangan & Keterangan \\
\hline 1 & Winbox Exploit & Berhasil & $\begin{array}{l}\text { Berhasil mendapatkan } \text { username dan password pada Mikrotik } \\
\text { versi 6.40 kebawa }\end{array}$ \\
\hline 2 & Brute-Force & Berhasil & $\begin{array}{l}\text { Berhasil mendapatkan username dan password pada router, } \\
\text { password yang digunakan merupakan password yang mudah } \\
\text { di tebak }\end{array}$ \\
\hline 3 & DoS & Berhasil & $\begin{array}{l}\text { Serangan DoS dengan DNS Flooding dapat meningkatkan } \\
\text { penggunaan CPU hingga 100\% }\end{array}$ \\
\hline
\end{tabular}


ISSN 2614-5278 (media cetak), ISSN 2548-8368 (media online)

Available Online at https://ejurnal.stmik-budidarma.ac.id/index.php/mib DOI 10.30865/mib.v5i3.2979

\subsubsection{Rekomendasi}

Agar serangan tidak terjadi lagi dimasa akan datang maka harus melakukan tindakan pencegahan, pada penelitian ini ada beberapa solusi yang dapat dilakukan untuk mencegah terjadinya serang seperti WinBox Exploitation, Brute-Force, dan DoS.

a. Upgrade versi router OS ke versi stabil yang terbaru. Langkah ini cocok di gunakan untuk menggulangi celah keamanan CVE-2018-14847 dari serangan Winbox Exploitation. Adapun langkah-langkahnya sebagai berikut: Download versi router terbaru di laman https://Mikrotik.com/download kemudian upload pada menu File, kemudian reboot router Mikrotik

b. Pengaturan hak akses pada router Mikrotik. Ada beberapa layanan akses pada router Mikrotik seperti Winbox, SSH, Web, dan lain-lain. Pada router Mikrotik kita dapat membatasi akses ke layanan tersebut berdasarkan IP Address atau Network Address yang dapat kita daftarkan pada router Mikrotik. Cara ini sangat cocok digunakan untuk menghindari celah keamanan CVE-2018-14847 serangan seperti Winbox Exploitation, dan Brute-Force. Meskipun penyerang mendapatkan username dan password, mereka tidak dapat login ke router Mikrotik karena akses ke router Mikrotik telah dibatasi berdasarkan IP Address atau Network Address tertentu. Adapun langkah-langkahnya sebagai berikut: Masuk Kemenu IP $\rightarrow$ Service dapat dilihat seperti pada gambar 8 berikut.

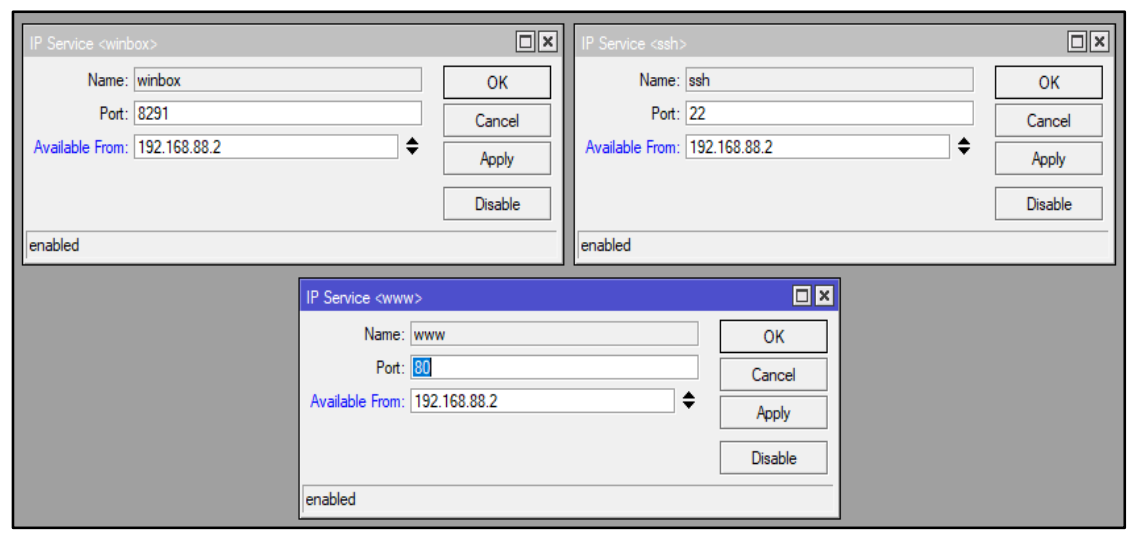

Gambar 8. Hak Akses Layanan Akses router Mikrotik

c. Gunakan Firewall untuk menutup akses ke user.dat. Langkah ini cocok digunakan untuk mencegah terjadinya serangan Winbox Exploitation. Adapun langkah-langkahnya sebagai berikut: Masuk ke terminal dan jalankan script berikut ini.

$$
\text { /ip firewall filter add action=reject chain=input content=user.dat reject-with=icmp-network-unreachable }
$$

Penyerang akan melakukan serangan ke router Mikrotik maka chain yang kita gunakan adalah input yang artinya semua paket yang masuk ke router Mikrotik akan kita beri tindakan dengan action reject sehingga penyerang tidak dapat mengambil informasi user.dat pada router Mikrotik. Hasil dapat dilihat pada gambar 10 berikut ini.

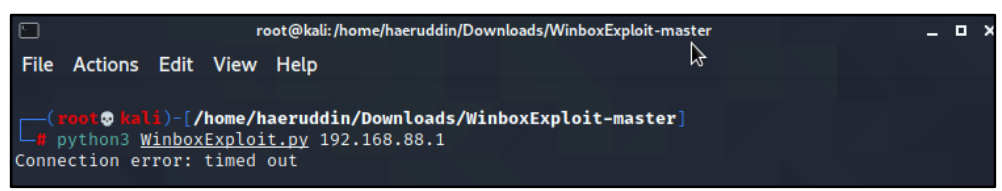

Gambar 9. Hasil serangan setelah mengimplementasikan Firewall

d. Firewall untuk menutup akses serangan DoS pada router Mikrotik. Serangan DoS menyerang protokol transport TCP dan UDP serta protokol ICMP. Untuk mencegah serangan ini kita dapat menggunakan fitur Firewall Raw untuk menutup akses DoS. Berikut script yang dapat digunakan pada Terminal Mikrotik untuk mencegah serangan DoS.

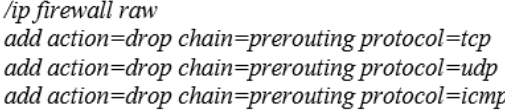

Gambar 11 adalah hasil konfigurasi yang telah dilakukan menggunakan terminal pada router Mikrotik. Gambar 12 adalah hasil pengujian serangan DoS setelah diterapkan Firewall. Hasil menunjukkan bahwa implementasi firewall dapat mencegah sekitar $79 \%$ penggunaan sumber daya prosesor. 
ISSN 2614-5278 (media cetak), ISSN 2548-8368 (media online)

Available Online at https://ejurnal.stmik-budidarma.ac.id/index.php/mib DOI 10.30865/mib.v5i3.2979

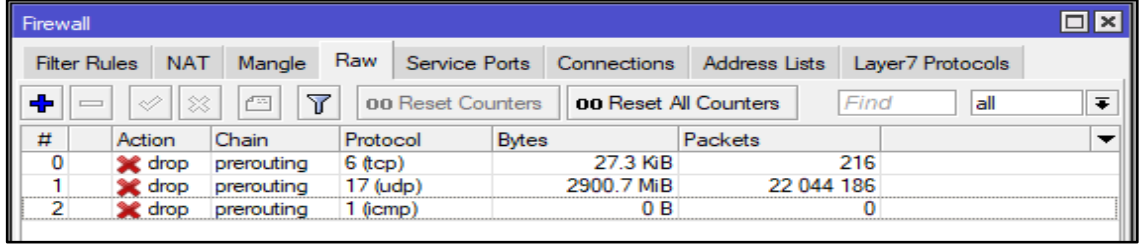

Gambar 10. Hasil implementasi rule untuk mengatasi DoS pada router Mikrotik

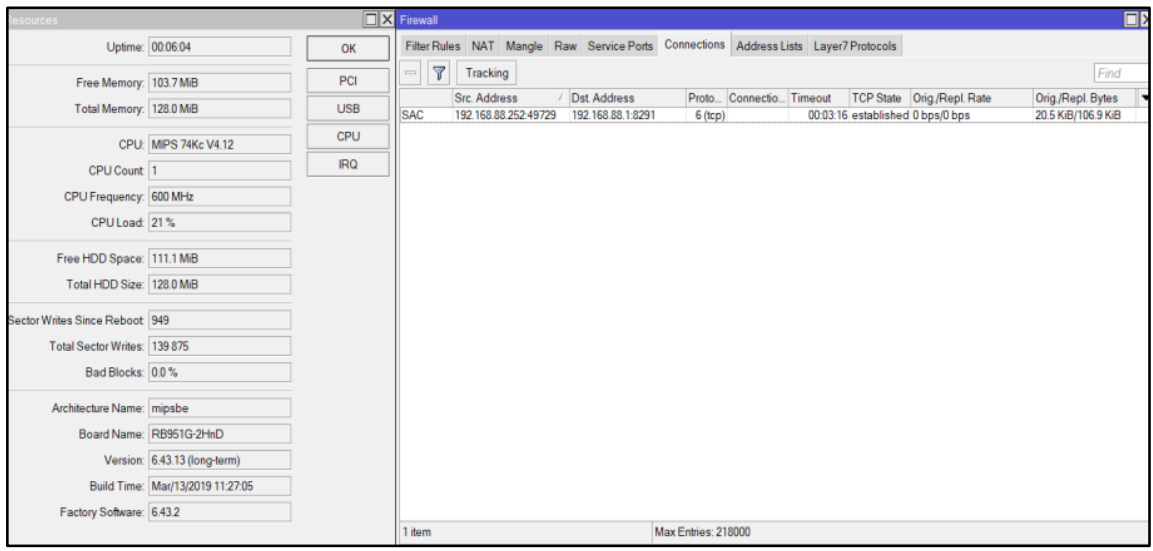

Gambar 11. Hasil serangan DoS setelah diimplementasikan Firewall

Tabel 2. Hasil serangan pada router Mikrotik setelah diterapkan sistem keamanan

\begin{tabular}{|c|c|c|c|c|}
\hline No & $\begin{array}{l}\text { Jenis } \\
\text { Serangan }\end{array}$ & Rekomendasi & $\begin{array}{l}\text { Status } \\
\text { Serangan }\end{array}$ & Keterangan \\
\hline \multirow[t]{3}{*}{1} & $\begin{array}{l}\text { Winbox } \\
\text { Exploitation }\end{array}$ & $\begin{array}{l}\text { Upgrade OS Router } \\
\text { Mikrotik Ke Versi } \\
\text { terbaru }\end{array}$ & Tidak Berhasil & $\begin{array}{l}\text { Peratas tidak berhasil mendapatkan username } \\
\text { dan password router Mikrotik }\end{array}$ \\
\hline & & $\begin{array}{l}\text { Pengaturan Hak } \\
\text { Akses kelayanan } \\
\text { router Mikrotik }\end{array}$ & Tidak Berhasil & $\begin{array}{l}\text { Peratas tidak dapat mengakses router Mikrotik } \\
\text { karena hanya IP Address tertentu yang dapat } \\
\text { mengakses router tersebut }\end{array}$ \\
\hline & & $\begin{array}{l}\text { Menggunakan } \\
\text { Firewall untuk } \\
\text { menutup akses ke } \\
\text { user.dat }\end{array}$ & Tidak Berhasil & $\begin{array}{l}\text { Peratas tidak mengakses data pada user.dat } \\
\text { menggunakan Winbox Exploitation, sehingga } \\
\text { username dan password tidak berhasil di } \\
\text { dapatkan }\end{array}$ \\
\hline 2 & Brute-Force & $\begin{array}{l}\text { Pengaturan Hak } \\
\text { Akses kelayanan } \\
\text { router Mikrotik }\end{array}$ & Tidak Berhasil & $\begin{array}{l}\text { Peratas tidak dapat mengakses router Mikrotik } \\
\text { karena hanya IP Address tertentu yang dapat } \\
\text { mengakses router Mikrotik }\end{array}$ \\
\hline 3 & DoS & $\begin{array}{l}\text { Menggunakan } \\
\text { Firewall Raw untuk } \\
\text { membatasi Prerouting } \\
\text { protokol tcp, } u d p \text {, dan } \\
\text { icmp }\end{array}$ & Tidak Berhasil & $\begin{array}{l}\text { Dengan menerapkan firewall dapat } \\
\text { menurunkan sebesar } 79 \% \text { penggunaan sumber } \\
\text { daya prosesor dari Serangan DoS dengan DNS } \\
\text { Flooding. }\end{array}$ \\
\hline
\end{tabular}

\section{KESIMPULAN}

Router merupakan perangkat jaringan yang digunakan menghubungkan pengguna, baik itu secara LAN maupun akses ke internet. Setiap pengguna dapat melakukan koneksi ke router dan dapat melakukan serangan. Serangan bisa saja datang dari pengguna LAN atau dari internet, sehingga perangkat router harus dalam kondisi yang aman. Ada banyak serangan yang bisa dilakukan pada router Mikrotik seperti Winbox Exploitation, Brute-Force, dan DoS. Untuk memastikan perangkat router dalam keadaan aman harus dilakukan pengujian, salah satu metode yang digunakan adalah penetration testing. Dari hasil pengujian dengan metode penetration testing membutuhkan beberapa cara untuk hasil yang maksimal yaitu harus melakukan pembaharuan atau upgrade router OS ke versi yang terbaru, membatasi akses kelayanan Winbox, SSH, Web ke router Mikrotik, mengimplementasikan firewall untuk menutup akses yang tidak diinginkan ke router Mikrotik.

\section{REFERENCES}

[1] C. Scholten, "Hacking the router : characterizing attacks targeting low-cost routers using a honeypot router," 2019. 
[2] J. M. Ceron, C. Scholten, A. Pras, and J. Santanna, "MikroTik Devices Landscape, Realistic Honeypots, and Automated Attack Classification," Proc. IEEE/IFIP Netw. Oper. Manag. Symp. 2020 Manag. Age Softwarization Artif. Intell. NOMS 2020, 2020, doi: 10.1109/NOMS47738.2020.9110336.

[3] H. L. J. Bijmans, T. M. Booij, and C. Doerr, "Just the tip of the iceberg: Internet-scale exploitation of routers for cryptojacking," Proc. ACM Conf. Comput. Commun. Secur., pp. 449-464, 2019, doi: 10.1145/3319535.3354230.

[4] Y. Fadlallah, M. Sbeiti, M. Hammoud, M. Nehme, and A. Fadlallah, "On the Cyber Security of Lebanon: A Large Scale Empirical Study of Critical Vulnerabilities," 8th Int. Symp. Digit. Forensics Secur. ISDFS 2020, 2020, doi: 10.1109/ISDFS49300.2020.9116446.

[5] C. Marrison, "DNS as an attack vector - And how businesses can keep it secure," Netw. Secur., vol. 2014, no. 6, pp. 1720, Jun. 2014, doi: 10.1016/S1353-4858(14)70061-3.

[6] D. Aprilianto, T. Fadila, and M. A. Muslim, "Sistem Pencegahan UDP DNS Flood Dengan Filter Firewall Pada Router Mikrotik," Techno.Com, vol. 16, no. 2, pp. 114-119, 2017, doi: 10.33633/tc.v16i2.1291.

[7] X. Liang and T. Znati, "On the performance of intelligent techniques for intensive and stealthy DDos detection," Comput. Networks, vol. 164, p. 106906, Dec. 2019, doi: 10.1016/j.comnet.2019.106906.

[8] B. Jaya, Y. Yunus, and S. Sumijan, "Peningkatan Keamanan Router Mikrotik Terhadap Serangan Denial of Service (DoS)," J. Sistim Inf. dan Teknol., vol. 2, pp. 5-9, 2020, doi: 10.37034/jsisfotek.v2i4.81.

[9] A. Amarudin, "Desain Keamanan Jaringan Pada Mikrotik Router OS Menggunakan Metode Port Knocking," J. Teknoinfo, vol. 12, no. 2, p. 72, 2018, doi: 10.33365/jti.v12i2.121.

[10] R. Liza, "PEMANFAATAN MIKROTIK ROUTER BOARD SEBAGAI PENGAMAN,” pp. 492-499, 2020.

[11] A. Bustami and S. Bahri, "Ancaman, Serangan dan Tindakan Perlindungan pada Keamanan Jaringan atau Sistem Informasi: Systematic Review," Unistek, vol. 7, no. 2, 2020.

[12] Y. Arta, A. Syukur, and R. Kharisma, "Simulasi Implementasi Intrusion Prevention System (IPS) Pada Router Mikrotik," It J. Res. Dev., vol. 3, no. 1, pp. 104-114, 2018, doi: 10.25299/itjrd.2018.vol3(1).1346.

[13] Haeruddin, "Security Design And Testing of Lan and Wlan Network in Mikrotik Router Using Penetration Testing Method FROM Mitm Attack," J. Informatics Telecommun. Eng., vol. 4, no. 1, pp. 119-127, 2020, doi: 10.31289/jite.v4i1.3832.

[14] M. C. Ghanem and T. M. Chen, "Reinforcement learning for efficient network penetration testing," Inf., vol. 11, no. 1, pp. 1-23, 2020, doi: 10.3390/info11010006.

[15] B. V. Tarigan, A. Kusyanti, and W. Yahya, "Analisis Perbandingan Penetration Testing Tool Untuk Aplikasi Web," J. Pengemb. Teknol. Inf. dan Ilmu Komput., vol. 1, no. 3, pp. 206-214, 2017.

[16] S. Syed et al., "Case Study : Intranet Penetration Testing of MUET," vol. 2020, no. December, pp. 17-19, 2019.

[17] S. A. Pamuji, C. Iswahyudi, and T. Informatika, "Analisis Dan Optimasi Dari Simulasi Keamanan Jaringan Menggunakan Firewall Mikrotik Studi Kasus Di Taman Pintar Yogyakarta,” J. JARKOM, vol. 7, no. 1, pp. 65-75, 2020.

[18] I. Kamilah and A. Hendri Hendrawan, "Analisis Keamanan Vulnerability pada Server Absensi Kehadiran Laboratorium di Program Studi Teknik Informatika," Pros. Semnastek, vol. 16, no. 0, pp. 1-9, 2019, [Online]. Available: https://jurnal.umj.ac.id/index.php/semnastek/article/view/5233. 